\title{
NEW PROBLEMS IN
}

\section{ASTROMETRY}

Edited by W. GLIESE, C. A. MURRAY, and R. H. TUCKER
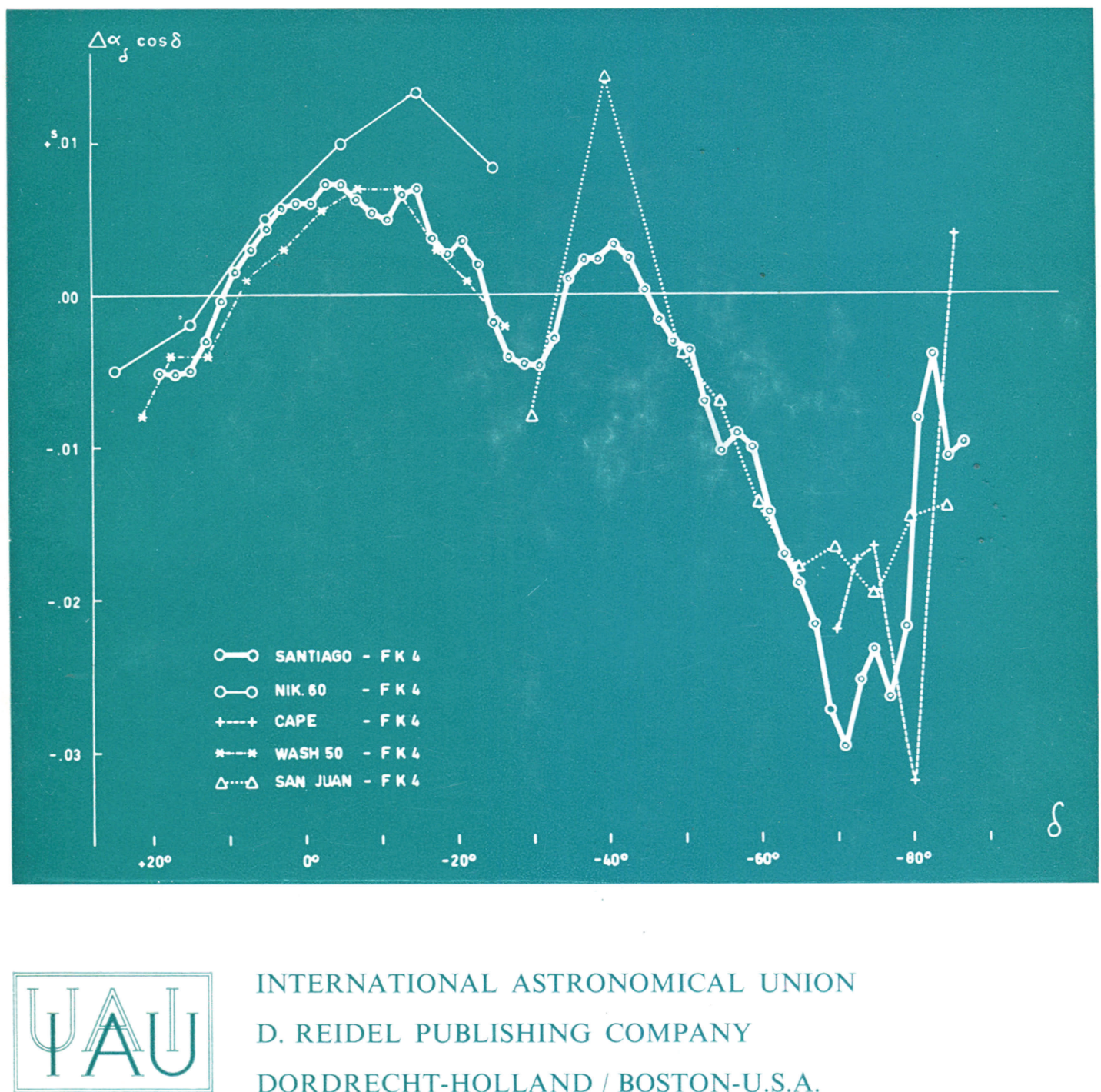

INTERNATIONAL ASTRONOMICAL UNION

D. REIDEL PUBLISHING COMPANY

DORDRECHT-HOLLAND / BOSTON-U.S.A. 


\section{NEW PROBLEMS IN}

ASTROMETRY

SYMPOSIUM No. 61

This Symposium reflected not only the continuing interest in the classical methods of optical astrometry, but also the exciting developments already achieved or to be expected within the next few years through the new techniques of radio interferometry, the use of large optical telescopes, and space astrometry. This was in fact the first symposium in which both optical and radio astrometrists participated. Collaboration between radio and optical observers, and the exploitation of these new techniques, were urged in three general Resolutions which were adopted at the end of the Symposium.

Audience:

Radio and optical astrometrists. 
NEW PROBLEMS IN ASTROMETRY 


\title{
INTERNATIONAL ASTRONOMICAL UNION \\ UNION ASTRONOMIQUE INTERNATIONALE
}

\author{
SYMPOSIUM No. 61
}

HELD IN PERTH, WESTERN AUSTRALIA, 13-17 AUGUST, 1973

\section{NEW PROBLEMS IN ASTROMETRY}

\author{
EDITED BY \\ WILHELM GLIESE \\ Astronomisches Rechen-Institut, Heidelberg, F.R. Germany \\ C. ANDREW MURRAY \\ Royal Greenwich Observatory, Herstmonceux, England \\ R. H. TUCKER \\ Royal Greenwich Observatory, Herstmonceux, England
}

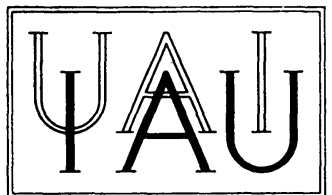

D. REIDEL PUBLISHING COMPANY

DORDRECHT-HOLLAND / BOSTON-U.S.A.

1974 
Published on behalf of

the International Astronomical Union

by

D. Reidel Publishing Company, P.O. Box 17, Dordrecht, Holland

All Rights Reserved

Copyright (C) 1974 by the International Astronomical Union

Sold and distributed in the U.S.A., Canada, and Mexico

by D. Reidel Publishing Company, Inc.

306 Dartmouth Street, Boston,

Mass. 02116, U.S.A.

Library of Congress Catalog Card Number 73-94453

Cloth edition: ISBN 9027704449

Paperback edition: ISBN 9027704457

No part of this book may be reproduced in any form, by print, photoprint, microfilm, or any other means, without written permission from the publisher

Printed in The Netherlands by D. Reidel, Dordrecht 


\section{TABLE OF CONTENTS}

PREFACE IX IX

\begin{tabular}{ll} 
LIST OF PARTICIPANTS XI \\
\hline
\end{tabular}

WALTER FRICKE / New Impetus to Astrometry (Inaugural Address) 1

\section{SESSION A / REFERENCE SYSTEMS}

G. VAN HER K / Report on IAU Colloquium No. 20, 'Meridian Astronomy' (Invited Paper)

WALTER FRICKE / Plans for the Improvement and Extension of the FK4

(Invited Paper)

W. GLIESE / Observations Relevant to the Improvement of the Fundamental System

Ia. S. IATSKIV, A. N. KURIANOVA, D. D. POLOZHENTSEV, and M. S. ZVEREV/

Report on the Compilation of the PFKSZ-2 Catalogue

C. Anguita, G. Carrasco, P. LOYola, A. A. Naumova, A. A. Nemiro, D. D. POlozhentsev, T. A. POlozhentseva, V. N. Shishiina, R. TAIBO, G. M. TIMASHKOVA, M. P. VARIN, V. A. VARINA, and M. S. ZVEREV/ On the Improvement of the $\alpha_{\delta}$ System of the FK4 Catalogue (Abstract)

G. M. PET ROV / Absolute Determination of Right Ascensions of Stars at High Geographical Latitude during the Polar Night

G. VAN HER K / On Stars with the most Favourable Background in Observational History

J. L. SCHOMBERT / Southern Reference Star Program: Progress Report

J. L. SCHOMBERT and T. E. CORBIN / Investigation of Magnitude Effect in the AGK3R Catalogue

R. BOUIGUE / Mouvements propres des étoiles de repère du catalogue photographique (Résumé)

DISCUSSION AFTER SESSION A

SESSION B / CURRENT AND FUTURE PROJECTS FOR SOUTHERN HEMISPHERE REFERENCE SYSTEMS

C. ANGuita / Observations in Chile and Results Related to Southern Hemisphere Systems (Invited Paper)

G. CARRASCO / Preliminary Results of Relative Declination Observations Made with the Repsold Meridian Circle at Cerro Calán 
E. HøG and I. NIKOLOFF / Observations by the Hamburg SRS-Expedition to Perth

K. N. Tavastsherna / On Progress and Methods of Reduction of the Melbourne Observations of Fundamental Stars

G. BILLAUD and S. DEBARBAT / Contribution des astrolabes à la détermination du système de référence dans l'hémisphère sud

M. S. Z VEREV / Some Urgent Programmes of Meridian Observations Especially for the Southern Hemisphere (Invited Paper)

R. H. TUCKER / Report on the Cape Participation in the Southern Reference Star Project

S. V. M. Clube and W. Nicholson / Report on the Cape Photographic Survey

E. D. HOFFLEIT / Potentialities of Yale Astrometric Materials

HARLEY WOOD / Thoughts on the Future of Photographic Catalogues

\section{SESSION C / RADIO ASTROMETRY}

B. ELSMORE / Radio Astrometry Using Connected-Element Interferometers (Invited Paper)

C. C. COUnSelman III / Positions of Extragalactic Radio Sources from Very Long Baseline Interferometry (Invited Paper)

J. S. GUBBAY, A. J. LEGG, and D. S. ROBERTSON / Position Solution of Compact Radio Sources Using Long Coherence VLBI

H. G. WAL TER / Accuracy Estimation of Astronomical Constants from Long Baseline Interferometer Observations (Abstract)

C. M. WADE / Radio and Optical Astrometry (Invited Paper)

J. N. Douglas / The Texas Radio Astrometric Survey (Abstract)

P. BROSCHE / Absolute Positions of Radio Sources Obtained with the NRAO Interferometer (Abstract)

J. L. FANSELOW and J. G. WILLIAMS / Determination of an Extragalactic Radio Source Position Catalogue Suitable for Use in Monitoring Geophysical Phenomena (Abstract)

\section{SESSION D / ASTROMETRY WITH LARGE TELESCOPES}

C. A. MURRAY / Proper Motion and Parallax Programmes for Large Telescopes (Invited Paper)

K. Aa. STRAND, R. S. HARRINGTON, and C. C. DAHN / The U.S. Naval Observatory Parallax Program

B. F. JONES / Report on the Herstmonceux I.N.T. Parallax Programme (Abstract)

W. J. LUYTEN / The Palomar Proper Motion Survey

R. W. HUnstead / Accurate Optical Positions Using the Palomar Sky Atlas 175 
P. LACROUTE / Reduction of Schmidt Photographs with the Aid of Reference

Marks on the Curved Plate (Abstract)

\section{SESSION E/PROPER MOTIONS AND GALACTIC PROBLEMS}

W. DIECK voss / Remarks on the Definition and Determination of Proper Motions (Invited Paper)

A. N. DEUTSCH and A. R. KLEMOLA / Proper Motions with respect to Galaxies (Invited Paper)

A. J. WeSSELINK / Report on the Yale-Columbia Southern Proper Motion Program

N. V. FATCHIKHIN / Comparison of Secular Parallaxes Determined from Proper Motions of Stars Relative to Galaxies at the Pulkovo and Lick Observatories

A. A. KISELEV / The Errors of Absolute Photographic Proper Motions of Stars Relative to Galaxies

CHR. DE VEGT / On the Project of a New Fourfold Coverage of the Northern Hemisphere

S. V. M. CLUBE / Stellar Kinematics and Galactic Research Involving Proper Motions (Invited Paper)

C. A. MURRAY / Progress Report on the Herstmonceux Programme of Measurement of Proper Motions in the Northern Selected Areas

H. YASUDA / Proper Motions of OB Stars in Both Hemispheres (Abstract)

J. DOMMANGET / Estimation de la précision des mouvements propres donnés dans un catalogue d'étoiles à l'aide des observations visuelles de couples stellaires optiques

\section{SESSION F/ASTRONOMICAL REFRACTION PROBLEMS}

G. TELEKI / The Present State and Future of the Astronomical Refraction Investigations (Abstract)

J. A. HUGHeS / Environmental Systematics and Astronomical Refraction, I (Abstract)

J. DOMMANGET / Les effets de la réfraction atmosphérique sur les coordonnées tangentielles en astrométrie (Résumé)

\section{SESSION G/ASTROMETRIC TECHNIQUES}

E. HøG / Modern Developments of the Meridian Circle (Invited Paper)

B. L. KLOCK and F. S. GAUSS / Instrumental Parameters of the U.S. Naval Observatory's Automatic Transit Circle (ATC) 
G. I. PINIGIN, L. A. SUKHAREV, and G. M. TIMASHKOVA / The Results of Investigations of the Pulkovo Horizontal Meridian Circle (HMC)

J. Kovalevsky / Projet de Centre de Recherches Astrométriques et Géodynamiques en France

J. KOVALEVSKY / Que pourra-t-on déduire des mesures de distance terre-lune par laser?

R. BOUigue / Sur la mesure des distances par télémétrie laser (Résumé)

P. BACCHUS and P. LACROUTE / Prospects of Space Astrometry

W. F. VAn ALtena, O. G. FRANZ, and L. W. FREDRICK / Astrometry with the Large Space Telescope

L. B. ROBINSON and S. VASILEVSKIS / Upgrading of the Lick-Gaertner Automatic Measuring System

N. M. PRATT / The COSMOS Plate Measuring Machine

P. M. ROU TLY / A New High Speed Measuring Machine for Astrometric Plates (Abstract)

H. EICHHORN and A. E. RUST / The Influence of the Reduction Model on the Systematic Accuracy of Adjusted Parameters (Abstract)

S. V. M. CLUBE / Star Positions from Overlapping Plates in the Cape Zone $-40^{\circ}$ to $-52^{\circ}$

CHR. DE VEGT and H. EBNER / A General Computer Program for the Application of the Rigorous Block-Adjustment Solution in Photographic Astrometry (Abstract)

J. DOMMANGET / La réduction des clichés astrographiques de champ quelconque (Résumé)

W. F. VAn altena / The Yerkes Observatory Photoelectric Parallax Scanner

W. D. HEINTZ / On Inconsistencies Found in Long-Term Parallax Series (Abstract)

S. YUmi, K. HURUKAWA, and Th. hirayama / Precise Reduction to the Apparent Places of Stars (Abstract)

GENERAL DISCUSSION, SUMMARY AND RESOLUTIONS

GENERAL DISCUSSION

BA R T J. BOK / Summary and Conclusions 